\title{
A novel mucin-sulphatase activity found in Burkholderia cepacia and Pseudomonas aeruginosa
}

\author{
HUGO-JAN JANSEN, C. ANTHONY HART*, JONATHAN M. RHODES $\dagger$, JONATHAN R. \\ SAUNDERS $\ddagger$ and JOHN W. SMALLEY \\ Departments of Clinical Dental Sciences, *Medical Microbiology and $\uparrow$ Medicine and $¥$ School of Biological \\ Sciences, University of Liverpool, Liverpool L69 $3 G A$
}

\begin{abstract}
Lung infections due to Burkholderia cepacia and Pseudomonas aeruginosa in patients with cystic fibrosis (CF) are common, are associated with respiratory morbidity and are a cause of mortality. Respiratory mucin in $\mathrm{CF}$ patients is highly sulphated, which increases its resistance to bacterial degradation. Desulphation increases the susceptibility of mucin to degradation by bacterial glycosidases and proteinases, and subsequent deglycosylation may facilitate bacterial colonisation by increasing available substrates and binding sites. This study determined whether clinical and environmental strains of $B$. cepacia and $P$. aeruginosa had the ability to desulphate mucin. Mucin-sulphatase activity was tested by incubating bacterial cell suspensions with ${ }^{35} \mathrm{~S}$-sulphated mucins purified from LS174T and HT29-MTX human colon carcinoma cell lines. These mucins were also used to test for differences in substrate specificities. Mucin-sulphatase activity was detected in all nine $B$. cepacia strains and in four of six $P$. aeruginosa strains. There was strain variability in the level of mucin-sulphatase activity. Aryl-sulphatase activities of Pseudomonas isolates (determined with methylumbelliferyl sulphate) were $c$. 20-fold higher than those of $B$. cepacia strains, and were independent of mucin-sulphatase activity. This is the first report to demonstrate desulphation of mucin by $B$. cepacia and $P$. aeruginosa. It is concluded that $B$. cepacia and $P$. aeruginosa produce one or more cell-bound glycosulphatase(s), in addition to aryl-sulphatase activity. Mucin-sulphatase activity of $B$. cepacia and $P$. aeruginosa may contribute to their association with airway infections in patients with cystic fibrosis.
\end{abstract}

\section{Introduction}

Burkholderia cepacia and Pseudomonas aeruginosa are opportunist pathogens that frequently colonise the respiratory tract of patients whose mucociliary clearance is defective [1,2]. The most striking of such diseases is cystic fibrosis (CF). CF is characterised by production of a highly viscid respiratory mucin which results in impaired mucociliary clearance, generalised mucus obstruction and colonisation of the airways by $P$. aeruginosa. The initial colonisation is with non-mucoid $P$. aeruginosa, but mucoid variants emerge later and are associated with chronic pulmonary infection [1]. The

Received 29 June 1998; revised version accepted 22 Sept. 1998.

Corresponding author: Professor C. A. Hart (e-mail: cahmm@liverpool.ac.uk). Present address: Department of Medical Microbiology, Royal Liverpool Hospital, Duncan Building, PO Box 147, Liverpool L69 3BX. reasons why these organisms colonise and persist in the respiratory tract are not fully understood. Although the prevalence of $B$. cepacia $(7 \%)$ [2] is not as high as that of $P$. aeruginosa (77\%) [3], it is increasing and epidemic spread of highly transmissible strains has been reported $[4,5]$. The clinical course of B. cepacia infection is variable, but $c$. $20 \%$ of patients succumb to the so-called 'cepacia syndrome', a rapidly fatal clinical deterioration with necrotising pneumonia and bacteraemia [2].

The severity of CF correlates with increased acidity of tracheo-bronchial mucin from such patients [6]. Part of the increased acidity is caused by mucin oversulphation $[7,8]$, possibly due to perturbations in intracellular sulphate activation or the transfer of activated sulphate to the mucin molecule [9], and part is the result of degradation of neutral mucin oligosaccharides by $P$. aeruginosa [10]. The sulphate esters impart a strong negative charge, which influences the physical properties of the mucus [11]. 
Sulphate is thereby likely to contribute significantly to the rheological properties of CF mucin. The increased tenacity of CF mucins impedes mucociliary clearance. Host defence at the epithelial surface is decreased by a raised $\mathrm{NaCl}$ concentration as a result of cystic fibrosis transmembrane regulator (CTFR)-associated defective $\mathrm{Cl}^{-}$transport across the airway epithelia [12]. Hampered mucus clearance and decreased host defence both strongly favour bacterial colonisation, but only if bacteria can find sufficient substrates to metabolise and sites for adherence.

In general, mucin is most heavily sulphated at bodily sites such as the mouth and the colon where there is a rich normal flora [13]. This sulphation protects the mucin from bacterial degradation unless the bacteria also have mucin-sulphatase activity [14]. Desulphation increases the susceptibility of mucin to breakdown by bacterial glycosidases and proteinases as it exposes formerly inaccessible oligosaccharides and, ultimately, the protein core [13]. The released carbohydrates and amino acids are likely to stimulate bacterial growth by analogy with mucin degradation by consortia of oral $[15,16]$ or colonic $[17,18]$ micro-organisms. Sulphate in mucin can be found along the oligosaccharide side chains bound to terminal and internal galactose, $\mathrm{N}$ acetylglucosamine and, occasionally, $\mathrm{N}$-acetylgalactosamine residues [19-25]. Both $P$. aeruginosa and $B$. cepacia have been reported to recognise and adhere to di- and tri-saccharide structures that are part of mucin side chains [26-28]. However, these antigenic structures may be shielded by other carbohydrate residues, sialic acid, or sulphate, and thus are not readily available for adhesion. Partial deglycosylation of mucin, of which desulphation is thought to be a first step, may promote bacterial colonisation by increasing available substrate and exposing cryptic binding sites.

In this study, clinical and environmental strains of $B$. cepacia and $P$. aeruginosa were investigated to determine the prevalence of mucin-sulphatase activity among these two respiratory pathogens.

\section{Materials and methods}

\section{Bacterial strains}

Non-mucoid strains of $B$. cepacia and $P$. aeruginosa (Table 1) were obtained from the collection of the Department of Medical Microbiology, University of Liverpool and comprised mostly isolates from previous studies $[3,29,30]$. All strains were identified by standard biochemical techniques and the API $20 \mathrm{NE}$ system (bioMerieux) and confirmed by the Central Public Health Laboratory (61 Colindale Avenue, London). Environmental strains of B. cepacia were described further by Butler et al. [29]. B. cepacia epidemic isolates were from different patients from different centres and confirmed to be separate strains by SDS-PAGE of whole protein and pyrolysis mass spectroscopy [30].

\section{Bacterial growth conditions}

Strains of $B$. cepacia and $P$. aeruginosa and the arylsulphatase negative control strain Escherichia coli $\mathrm{K} 12$ that were tested for aryl-sulphatase activity and sulphatase activity against LS174T mucin were grown in triplicate on blood agar containing defibrinated horse blood $5 \% \mathrm{v} / \mathrm{v}$, for $24 \mathrm{~h}$ at $37^{\circ} \mathrm{C}$, harvested with sterile swabs, washed once in $0.1 \mathrm{M}$ Tris, $0.15 \mathrm{M} \mathrm{NaCl}$, pH 7.0 (Tris-saline) and resuspended in $5 \mathrm{ml}$ of Tris-saline. Strains of $B$. cepacia that were tested for sulphatase activity against HT29-MTX mucin were grown on five plates of blood agar for $24 \mathrm{~h}$ at $37^{\circ} \mathrm{C}$. Mucin-sulphatase positive control strain Bacteroides thetaiotaomicron NCTC 10582 was grown anaerobically on 10 plates of blood agar for $48 \mathrm{~h}$. The protein content of bacterial cell suspensions was estimated by the biuret bicinchoninic acid (BCA) protein assay (Sigma) with bovine serum albumin as a standard.

\section{Mucin}

${ }^{35} \mathrm{SO}_{3}$-labelled human colonic mucin was obtained after incorporation of ${ }^{35} \mathrm{SO}_{4}{ }^{2-}$ into mucins secreted by

Table 1. Source and description of strains used in this study

\begin{tabular}{llll}
\hline Organism & Strain & Source & Description \\
\hline B. cepacia & D505 & Liverpool & Cepacia syndrome, epidemic \\
$B$. cepacia & D538 & Liverpool & Cepacia syndrome, epidemic \\
B. cepacia & E195 & Sheffield & CF isolate, epidemic \\
$B$. cepacia & E241 & Edinburgh & CF isolate, epidemic \\
$B$. cepacia & E242 & Edinburgh & CF isolate, non-epidemic \\
$B$. cepacia & E243 & Edinburgh & Environmental strain \\
$B$. cepacia & E244 & Edinburgh & Environmental strain \\
$B$. cepacia & E245 & Edinburgh & Environmental strain \\
$B$. cepacia & E246 & Edinburgh & Environmental strain \\
$P$. aeruginosa & E546 & Liverpool & CF isolate \\
$P$. aeruginosa & E551 & Liverpool & CF isolate \\
$P$. aeruginosa & E567 & Liverpool & CF isolate \\
$P$. aeruginosa & E575 & Liverpool & CF isolate \\
$P$. aeruginosa & E601 & Liverpool & CF isolate \\
$P$. aeruginosa & PAO-1 & BW Holloway, LaFroke & Laboratory strain \\
\hline
\end{tabular}


the human colon carcinoma cell lines LS174T and HT29-MTX. Cells were grown in Dulbecco's Modified Eagle's Medium (Life Sciences) supplemented with $2 \mathrm{mM}$ L-glutamine, penicillin $100 \mathrm{U} / \mathrm{ml}$, streptomycin $100 \mu \mathrm{g} / \mathrm{ml}$ and fetal calf serum $(10 \% \mathrm{v} / \mathrm{v}$ for HT29MTX; $15 \% \mathrm{v} / \mathrm{v}$ for LS174T) (DMEM) at $37^{\circ} \mathrm{C}$, in air with $\mathrm{CO}_{2} 5 \%$. Spent medium was replaced with fresh DMEM on alternate days. After cells had been confluent for 7 days, they were incubated for $72 \mathrm{~h}$ in low-sulphate DMEM (Life Sciences) with $50 \mu \mathrm{Ci} / \mathrm{ml}$ $\mathrm{Na}_{2-}{ }^{35} \mathrm{~S}_{3} \mathrm{O}_{4}$ (NEN). Low-sulphate DMEM contains a quarter of the sulphate concentration in normal DMEM and was used to promote ${ }^{35} \mathrm{SO}_{4}{ }^{2-}$ incorporation [31]. ${ }^{35} \mathrm{~S}$-labelled-sulphated mucins were purified from cells and cell culture medium by gel filtration on Sepharose CL-4B (Pharmacia) and Superose-6 FPLC (Pharmacia) as described previously [32]. Mucin-containing fractions were pooled, lyophilised and de-salted on prepacked gravity-fed PD10-Sephadex G25M columns $(5 \times 1.5 \mathrm{~cm}$; Pharmacia) equilibrated in $0.1 \mathrm{M}$ Tris$\mathrm{HCl}, \mathrm{pH} 7.0$.

\section{Mucin-sulphatase assay}

Mucin-sulphatase (MS) activity was measured by the release of ${ }^{35} \mathrm{SO}_{4}{ }^{2-}$ after incubation of bacterial cells from replicate cultures of $B$. cepacia, $P$. aeruginosa and $E$. coli with ${ }^{35} \mathrm{~S}$-sulphated mucin by a method slightly modified from that previously described by Smalley et al. [33]. Samples of bacterial cell suspensions containing $c .1 \mathrm{mg}$ of whole-cell protein were incubated at $37^{\circ} \mathrm{C}$ with $11000 \mathrm{dpm}(0.005 \mu \mathrm{Ci})$ of ${ }^{35} \mathrm{SO}_{4}$-labelled mucin in a final volume of $2.5 \mathrm{ml}$ of $0.1 \mathrm{M}$ Tris, $\mathrm{pH} 7.0$. Incubation was stopped after $48 \mathrm{~h}$ by boiling for $3 \mathrm{~min}$. Bacterial cells were centrifuged and the supernate was passed through PD10-Sephadex G25M columns $(5 \times 1.5 \mathrm{~cm})$. The mucin substrate eluted in the void volume $(3.5 \mathrm{ml})$ whilst cleaved ${ }^{35} \mathrm{SO}_{4}{ }^{2-}$ was washed from the column with a further $6 \mathrm{ml}$ of Tris buffer and precipitated by addition of $1 \mathrm{ml}$ of $0.1 \mathrm{M} \mathrm{BaCl}_{2}$ and $0.9 \mathrm{ml}$ of $0.1 \mathrm{M} \mathrm{K} \mathrm{K}_{2} \mathrm{SO}_{4}$. This method precipitates free sulphate but not sulphated monosaccharides [34]. The precipitate was washed once, resuspended in $0.5 \mathrm{ml}$ of Tris buffer, and radioactivity was quantified by $\beta$-scintillation counting. Bact. thetaiotaomicron [14] and a faecal homogenate, prepared from pooled faeces from six patients with ulcerative colitis [34], served as positive controls $(\mathrm{n}=8) ; 13$ samples of ${ }^{35} \mathrm{~S}$-sulphated mucin in Tris buffer were used as negative controls to assess spontaneous background hydrolysis of sulphate.

\section{Aryl-sulphatase assay}

Aryl-sulphatase (AS) activity was assayed by release of 4-methylumbelliferone (MUF) after incubation of bacterial cells (c. $60 \mu \mathrm{g}$ protein) from triplicate cultures of B. cepacia, $P$. aeruginosa and Bact. thetaiotaomicron at $37^{\circ} \mathrm{C}$ with $170 \mu \mathrm{M}$ 4-methylumbelliferyl sulphate in a final volume of $200 \mu \mathrm{l}$ of $0.1 \mathrm{M}$ Tris, $\mathrm{pH} 7.0$. Incubation was stopped after $24 \mathrm{~h}$ by boiling for $3 \mathrm{~min}$, cellular debris was centrifuged and the volume adjusted to $3 \mathrm{ml}$ with $2.2 \mathrm{mM} \mathrm{NaOH}$ to a final $\mathrm{pH}$ of 10.3 (the $\mathrm{pH}$ optimum of fluorescence intensity of MUF [35]). The amount of released sulphate was calculated from the concentration of free MUF as detected with a Model 1000 Fluorescence Spectrophotometer (excitation $363 \mathrm{~nm}$, emission $450 \mathrm{~nm}$; Perkin Elmer). Free MUF (Sigma) was used as a standard. Strains of $P$. aeruginosa [36] and faecal homogenate from patients with ulcerative colitis were used as positive controls; E. coli $\mathrm{K} 12$ and Tris buffer were negative controls. Suspensions of bacterial cells in Tris buffer served to control for autofluorescence of bacterial products.

\section{Statistical analysis}

The data are expressed as means and SEM and amounts of sulphate released by bacterial strains were compared with that released by the Tris buffer control. Differences were analysed by the one-tailed Student's $t$ test and differences at $\mathrm{p}<0.05$ were considered to be significant.

\section{Results}

With an assay in which ${ }^{35} \mathrm{SO}_{4}{ }^{2-}$ was cleaved from ${ }^{35} \mathrm{~S}$ labelled human colonic mucin and precipitated with $\mathrm{BaCl}_{2}$, mucin-sulphatase activity was shown to be associated with whole cells of $B$. cepacia and $P$. aeruginosa clinical and environmental isolates. All isolates of $B$. cepacia possessed MS activity against one or both ${ }^{35} \mathrm{~S}$-mucins (Fig. 1). Four of nine isolates were active against either LS174T or HT29-MTX mucin; the other five isolates were active against both. Sulphatase activity against LS174T-derived mucin was detected in four of the six $P$. aeruginosa isolates. Interstrain MS activity of the test isolates varied, but MS activity was usually similar to or greater than that displayed by the positive control, Bact. thetaiotaomicron. Of the MS-positive isolates, the average release of radioactivity minus that of the Tris negative control for B. cepacia, as a percentage of the total available, was $2.8 \% \mathrm{SD} 3.0 \%(\mathrm{n}=7$, range $0.5-9 \%)$ for $\mathrm{LS} 174 \mathrm{~T}$ mucin and $4.3 \%$ SD $2.6 \%(n=7$, range $2-10 \%)$ for HT29-MTX mucin. The average sulphatase desulphation of LS174T mucin by $P$. aeruginosa $(2.5 \%$ SD $0.7, \mathrm{n}=4)$ was similar to that of $B$. cepacia, but the range of interstrain MS activity was smaller $(2-3.5 \%)$. The faecal homogenate liberated $38 \%$ of radiolabelled sulphate from LS174T mucin, but only 5.5\% from HT29-MTX mucin. Clinical isolates of $B$. cepacia did not appear to have MS activities different from those of environmental strains, as was the case for epidemic versus nonepidemic isolates. Furthermore, sulphatase activity against LS174T-derived mucin was detected in E. coli.

AS activity was demonstrated in all isolates of $B$. cepacia and P. aeruginosa (Fig. 2). The activities of 


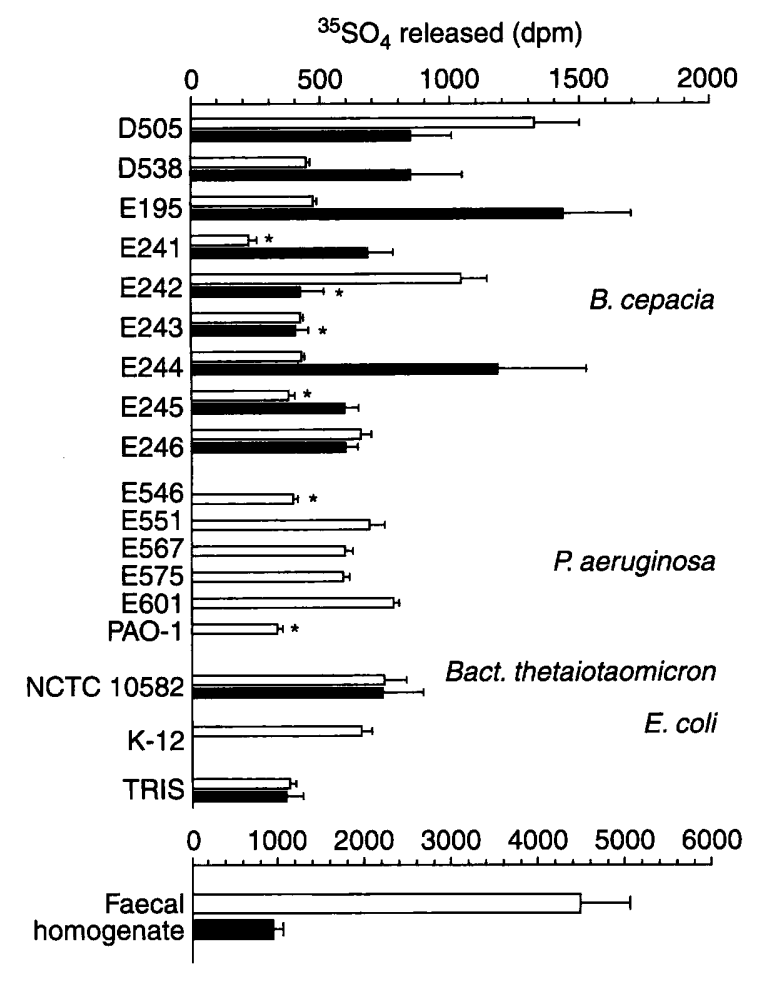

Fig. 1. Mucin-sulphatase activity of $B$. cepacia and $P$. aeruginosa strains against ${ }^{35} \mathrm{~S}$-labelled mucins. Activity was determined by release of ${ }^{35} \mathrm{SO}_{4}{ }^{2-}$ after incubation of whole bacterial cells with ${ }^{35} \mathrm{~S}$-sulphated mucin from human colon carcinoma LS174T ( $\square$ ) and HT29-MTX (ם) cell lines at $37^{\circ} \mathrm{C}$ for $48 \mathrm{~h}$. Bact. thetaiotaomicron and a faecal homogenate from patients with ulcerative colitis were used as positive controls. Tris buffer was used a negative control. Results are expressed as mean and SEM $\mathrm{dpm}$ of released ${ }^{35} \mathrm{~S}$-sulphate and differences between bacterial strains versus the negative control were statistically significant $(\mathrm{p}<0.05)$ unless indicated $\left({ }^{*}\right)$.

the $B$. cepacia isolates were all similar, but were $c$. 20-fold lower than those of $P$. aeruginosa.

AS activity in $B$. cepacia, $P$. aeruginosa, Bact. thetaiotaomicron and the (AS-negative) E. coli control strain did not correlate with the presence of MS activity, indicating that the activities are mediated by different enzymes. As suspensions of washed bacterial cells were used, the mucin- and aryl-sulphatases detected are likely to be cell-wall-associated or localised in the periplasmic space.

\section{Discussion}

This study demonstrated for the first time that $B$. cepacia and $P$. aeruginosa can desulphate mucin. MS activity with $P$. aeruginosa has not been reported previously and is mediated by an enzyme that differs from the aryl- [36], choline- [37] and alkyl- [38] sulphatase activities that have been known for some time. No sulphatase activity of any kind has been demonstrated before in B. cepacia. The present study further indicates that, although the level of MS activity

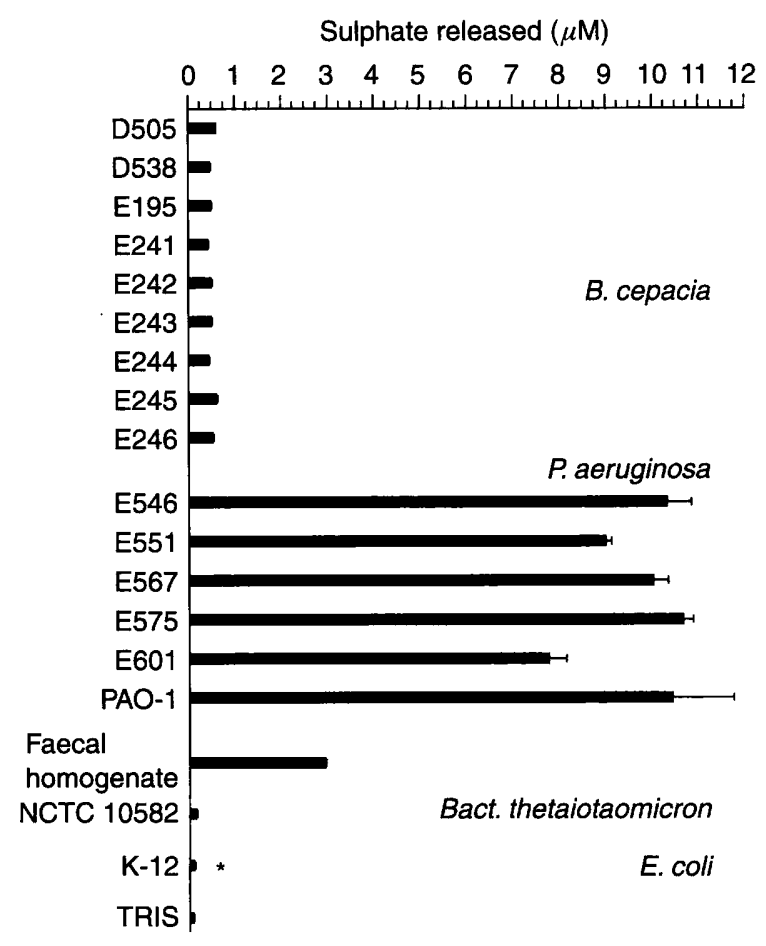

Fig. 2. Aryl-sulphatase activity of $B$. cepacia and $P$. aeruginosa strains. Activity was determined by release of sulphate, yielding free methylumbelliferone, after incubation of washed bacterial cells with methylumbelliferyl sulphate for $24 \mathrm{~h}$ at $37^{\circ} \mathrm{C}$. A faecal homogenate from patients with ulcerative colitis acted as positive control. Negative controls were $E$. coli and Tris-buffer. Results are expressed as mean and SEM $(n=3)$ of released sulphate and differences between bacterial strains versus the Tris buffer control were statistically significant $(\mathrm{p}<0.05)$ unless indicated $\left({ }^{*}\right)$.

may vary considerably between isolates, this ability is found commonly in the two genera and they are relatively active as compared with control organisms from the gut such as Bact. thetaiotaomicron and E. coli.

The role of sulphomucins and the importance of mucin desulphation in the gut was reviewed recently [13]. In colonic mucin, sulphate is ester-linked to C-3 and C-6 of galactose and $\mathrm{N}$-acetylglucosamine residues $[19,39]$. As sulphate is found on the same positions and residues in human tracheobronchial and CF-derived mucin [20-22] it seems likely that the sulphatases detected in $B$. cepacia and $P$. aeruginosa can also degrade mucin from these sources.

To ensure a maximum release of sulphate from the substrate, an excess of the bacterial suspension in relation to available substrate was used in both MS and AS assays and incubation times were relatively long compared with other studies [33, 34, 40]. Hence, sulphatase activity is expressed as the release of absolute amounts of sulphate, rather than release of sulphate $/ \mathrm{mg}$ of cell protein, or release of sulphate/ $\mathrm{mg} / \mathrm{min}$. 
Approximately $38 \%$ of radiolabelled sulphate was released from the LS174T mucin by the faecal homogenate. This is similar to the $30 \%$ of sulphate released by the faecal homogenate from mucin from cultured human colonic biopsies [34] and the $33 \%$ of sulphate released from rat gastric mucin by a purified glycosulphatase from Prevotella sp. RS2 [41]. However, the sulphate release from HT29-MTX mucin by the faecal homogenate was seven-fold lower, suggesting that there is substrate heterogeneity. The differences in sulphatase activity between test isolates and controls observed for mucins from the two cell lines also indicate substrate heterogeneity. This implies that mucin secreted by the LS174T cell line contains different sulphated oligosaccharide structures from mucin produced by the HT29-MTX cell line. Unfortunately, biochemical data to characterise these differences are not yet available. However, LS174T produces a mucin with the protein core (apomucin) predominantly encoded by the MUC2 gene [42], whilst the majority of apomucins secreted by HT29MTX are encoded by $M U C 5 A / C$ and $M U C 5 B$ [43], and mucin glycosylation is modulated by the aminoacid sequence of the protein core [44]. Lower sulphate release from HT29-MTX mucin by faecal homogenate may be due to the substrate specificity of the glycosulphatases not matching the remaining sulphated sugars in the mucin oligosaccharide chains.

$P$ aeruginosa has few glycosidase activities [45], but no data are available for $B$. cepacia. In colonic mucins, the oligosaccharide side chains are densely packed and may vary in length from 2 to 12 residues and sulphate is linked to galactose and $\mathrm{N}$-acetylglucosamine along the chains [46]. The low sulphate release by bacterial samples is presumably due to steric hindrance of the neighbouring oligosaccharide side chains impeding the access of glycosulphatases to the carbohydrate side chains in the absence of bacterial glycosidases, particularly when sulphate is linked to carbohydrate residues within the side chain, or to non-matching substrate specificities of the glycosulphatases.

The B. cepacia and $P$. aeruginosa mucin- and arylsulphatases detected are likely to be localised either on the cell wall or in the periplasmic space, as is the case for the glycosulphatase of Prevotella sp. RS2 [41] and MS activities in oral streptococci [33]. It is likely that adhesion to the mucin molecules is a prerequisite for desulphation. Bacterial adherence to CF mucin has been reported for $P$ aeruginosa and $B$. cepacia $[27,47]$. In addition to cell-bound activities, Streptococcus salivarius and $S$. gordonii produce extracellular MS activities [48], and mucin-specific glycosulphatases are found extracellularly in Bact. thetaiotaomicron [14], Helicobacter pylori [49], Ruminococcus torques [50] and Bifidobacterium sp. [50].

Desulphation increases susceptibility of mucin to degradation by bacterial glycosidases and proteinases
[13]. $P$. aeruginosa can break down neutral mucins in the sputum of CF patients [10]. It produces proteinases, some glycosidases [45] and a putative neuraminidase that is active against mucins [51], although the latter activity may be rare [52]. Desulphation and desialylation of the acidic mucins will increase the amount of the neutral mucin fraction degradable by the organism. In addition, this activity will expose formerly inaccessible oligosaccharides to glycosidases of its own and other infecting bacteria such as $S$. pneumoniae and Staphylococcus aureus, thus accelerating mucin breakdown.

Desialylation greatly decreases adhesion of $P$. aeruginosa to CF salivary mucin, not only indicating that sialic acid plays an important role in binding [53], but also that desialylation may slow further colonisation. Moreover, $P$. aeruginosa recognises and adheres to type 1 (Gal $\beta 1-3 \mathrm{GlcNAc})$ and type 2 (Gal $\beta 1-4 \mathrm{GlcNAc})$ backbone structures of mucin carbohydrate side chains $[26,28]$, which are abundant in tracheobronchial $[20,21]$, colonic [19] and salivary [25] mucins. Other neutral oligosaccharide structures, including asialo GM1 and asialo GM2, are recognised by both $P$. aeruginosa and $B$. cepacia [28]. The disaccharides GlcNAc $\beta 1-3-G a l N A c$ or GlcNAc $\beta 1-6-G a l N A c$ found, for example, in core 3 and core 4 mucin oligosaccharide configurations [27] may also be binding receptors for $B$. cepacia. However, these structures, such as the Gal $\beta(1-3)$-GlcNAc backbone which is a major site of sulphation of colonic mucins $[39,54]$, may be shielded by other carbohydrate residues, sialic acid, or sulphate, and thus not be readily accessible for adhesion. The results of the above studies $[26,28,53]$ indicate that various adhesins with different carbohydrate specificities exist on $P$. aeruginosa. Conflicting data about receptor involvement in the binding of $P$. aeruginosa to mucin were reported by Sajjan and co-workers [47]. They found that $P$. aeruginosa bound non-specifically to CF mucin, intestinal mucin, bovine serum albumin, casein and other structurally unrelated proteins by hydrophobic interactions. Partial deglycosylation of mucin may facilitate bacterial colonisation by exposing cryptic binding sites for $B$. cepacia and possibly $P$. aeruginosa. Furthermore, the released sugars are likely to promote bacterial growth, including the growth of those that metabolise carbohydrates but do not have glycosidase activities themselves, by analogy with mucin degradation by consortia of oral $[15,16]$ or colonic $[17,18]$ micro-organisms.

We thank J.R. Govan and G.R. Gibson for their generous gifts of bacterial strains. This study was supported by the Wellcome Trust.

\section{References}

1. Govan JRW, Deretic V. Microbial pathogenesis in cystic fibrosis: mucoid Pseudomonas aeruginosa and Burkholderia cepacia. Microbiol Rev 1996; 60: 539-574. 
2. Govan JRW, Hughes JE, Vandamme P. Burkholderia cepacia: medical, taxonomic and ecological issues. $J$ Med Microbiol 1996; 45: 395-407.

3. Cheng K, Smyth RL, Govan JRW et al. Spread of a $\beta$-lactam resistant Pseudomonas aeruginosa in a cystic fibrosis clinic. Lancet 1996; 348: 639-642.

4. Govan JRW, Brown PH, Maddison J et al. Evidence for transmission of Pseudomonas cepacia by social contact in cystic fibrosis. Lancet 1993; 342: 15-19.

5. Sun L, Jiang R-Z, Steinbach $\mathrm{S}$ et al. The emergence of a highly transmissible lineage of $\mathrm{cbl}^{+}$Pseudomonas (Burkholderia) cepacia causing CF centre epidemics in North America and Britain. Nature Med 1995; 1: 661-666.

6. Chace KV, Leahy DS, Martin R, Carubelli R, Flux M, Sachdev GP. Respiratory mucous secretions in patients with cystic fibrosis: relationship between levels of highly sulfated mucin component and severity of the disease. Clin Chim Acta 1983; 132: $143-155$

7. Chace KV, Flux M, Sachdev GP. Comparison of physicochemical properties of purified mucus glycoproteins isolated from respiratory secretions of cystic fibrosis and asthmatic patients. Biochemistry 1985; 24: 7334-7341.

8. Cheng PW, Boat TF, Cranfill K, Yankaskas JR, Boucher RC. Increased sulfation of glycoconjugates by cultured nasal epithelial cells from patients with cystic fibrosis. $J$ Clin Invest 1989; 84: 68-72.

9. Mohapatra NK, Cheng P-W, Parker JC et al. Alteration of sulfation of glycoconjugates, but not sulfate transport and intracellular inorganic sulfate content in cystic fibrosis airway epithelial cells. Pediatr Res 1995; 38: 42-48.

10. Houdret N, Ramphal R, Scharfman A et al. Evidence for the in vivo degradation of human respiratory mucins during Pseudomonas aeruginosa infection. Biochim Biophys Acta 1989; 992: 96-105.

11. Strous GJ, Dekker J. Mucin-type glycoproteins. Crit Rev Biochem Mol Biol 1992; 27: 57-92.

12. Smith JJ, Travis SM, Greenberg EP, Welsh MJ. Cystic fibrosis airway epithelia fail to kill bacteria because of abnormal airway surface fluid. Cell 1996; 85: 229-236.

13. Roberton AM, Wright DP. Bacterial glycosulphatases and sulphomucin degradation. Can $J$ Gastroenterol 1997; 11: 361-366.

14. Tsai HH, Hart CA, Rhodes JM. Production of mucin degrading sulphatase and glycosidases by Bacteroides thetaiotaomicron. Lett Appl Microbiol 1991; 13: 97-101.

15. Bradshaw DJ, Homer KA, Marsh PD, Beighton D. Metabolic cooperation in oral microbial communities during growth on mucin. Microbiology 1994; 140: 3407-3412.

16. Van der Hoeven JS, Camp PJM. Synergistic degradation of mucin by Streptococcus oralis and Streptococcus sanguis in mixed chemostat cultures. J Dent Res 1991; 70: 1041-1044.

17. Hoskins LC. Human enteric population ecology and degradation of gut mucins. Dig Dis Sci 1981; 26: 769-772.

18. Willis $\mathrm{CL}$, Cummings $\mathrm{JH}$, Neale $\mathrm{G}$, Gibson $\mathrm{GR}$. In vitro effects of mucin fermentation on the growth of human colonic sulphate-reducing bacteria. Anaerobe 1996; 2: 117-122.

19. Capon C, Laboisse CL, Wieruszeski J-M, Maoret J-J, Augeron $\mathrm{C}$, Fournet B. Oligosaccharide structures of mucins secreted by the human colonic cancer cell line CL.16E. J Biol Chem 1992; 267: 19248-19257.

20. Lo-Guidice J-M, Herz H, Lamblin G, Plancke Y, Roussel P, Lhermitte M. Structures of sulfated oligosaccharides isolated from the respiratory mucins of a non-secretor $\left(\mathrm{O}, \mathrm{Le}^{(\mathrm{a}+\mathrm{b}-)}\right)$ patient suffering from chronic bronchitis. Glycoconj $J$ 1997; 14: $113-125$.

21. Lo-Guidice J-M, Wieruszeski J-M, Lemoine J, Verbert A, Roussel P, Lamblin G. Sialylation and sulfation of the carbohydrate chains in respiratory mucins from a patient with cystic fibrosis. $J$ Biol Chem 1994; 269: 18794-18813.

22. Mawhinney TP, Adelstein E, Gayer DA, Landrum DC, Barbero GJ. Structural analysis of monosulfated side-chain oligosaccharides isolated from human tracheobronchial mucous glycoproteins. Carbohydr Res 1992; 223: 187-207.

23. Sangadala S, Bhat UR, Mendicino J. Structures of sulfated oligosaccharides in human trachea mucin glycoproteins. $\mathrm{Mol}$ Cell Biochem 1993; 126: 37-47.

24. Slomiany BL, Murty VLN, Slomiany A. Structural features of carbohydrate chains in human salivary mucins. Int $J$ Biochem 1993; 25: 259-265.
25. Wu AM, Csako G, Herp A. Structure, biosynthesis, and function of salivary mucins. Mol Cell Biochem 1994; 137: 39-55.

26. Ramphal R, Carnoy C, Fievre S et al. Pseudomonas aeruginosa recognizes carbohydrate chains containing type 1 (Gal $\beta 1-3 \mathrm{GlcNAc})$ or type 2 (Gal $\beta 1-4 \mathrm{GlcNAc})$ disaccharide units. Infect Immun 1991; 59: 700-704.

27. Sajjan US, Corey M, Karmali MA, Forstner JF. Binding of Pseudomonas cepacia to normal human intestinal mucin and respiratory mucin from patients with cystic fibrosis. $J$ Clin Invest 1992; 89: 648-656.

28. Scharfman A, Van Brussel E, Houdret N, Lamblin G, Roussel P. Interactions between glycoconjugates from human respiratory airways and Pseudomonas aeruginosa. Am J Respir Crit Care Med 1996; 154: S163-S169.

29. Butler SL, Doherty CJ, Hughes JE, Nelson JW, Govan JRW. Burkholderia cepacia and cystic fibrosis: do natural environments present a potential hazard? J Clin Microbiol 1995; 33: 1001-1004.

30. Corkill JE, Sisson PR, Smyth A et al. Application of pyrolysis mass spectroscopy and SDS-PAGE in the study of the epidemiology of Pseudomonas cepacia in cystic fibrosis. $J$ Med Microbiol 1994; 41: 106-111.

31. Diaz S, Varki A. Metabolic radiolabeling of animal cell glycoconjugates. In: Coligan JE, Dunn BM, Ploegh HL, Speichler DW, Wingfield PT (eds) Current protocols in protein science, vol 1. New York, John Wiley and Sons. 1995: 12.2.1-12.2.15.

32. Campbell BJ, Finnie IA, Hounsell EF, Rhodes JM. Direct demonstration of increased expression of Thomsen-Friedenreich (TF) antigen in colonic adenocarcinoma and ulcerative colitis mucin and its concealment in normal mucin. $J$ Clin Invest 1995; 95: 571-576.

33. Smalley JW, Dwarakanath D, Rhodes JM, Hart CA. Mucinsulphatase activity of some oral streptococci. Caries Res 1994; 28: $416-420$.

34. Tsai HH, Sunderland D, Gibson GR, Hart CA, Rhodes JM. A novel mucin sulphatase from human faeces: its identification, purification and characterization. Clin Sci 1992; 82: 447-454.

35. Bascomb S. Enzyme tests in bacterial identification. In: Colwell RR, Grigorova R (eds) Methods in microbiology, vol 19. Current methods for classification and indentification of microorganisms. Academic Press. 1987: 105-160.

36. Delisle GJ, Milazzo FH. The isolation of arylsulphatase isoenzymes from Pseudomonas aeruginosa. Biochim Biophys Acta 1970; 212: 505-508.

37. Lucas JJ, Burchiel SW, Segel IH. Choline sulfatase of Pseudomonas aeruginosa. Arch Biochem Biophys 1972; 153: 664-672.

38. Fitzgerald WJ, Knight LC. Physiological control of alkylsulfatase synthesis in Pseudomonas aeruginosa: effects of glucose, glucose analogs, and sulfur. Can $J$ Microbiol 1977; 23: 1456-1464.

39. Kuhns W, Jain RK, Matta KL et al. Characterization of a novel mucin sulphotransferase activity synthesising sulphated $O$ glycan core 1, 3-sulphate-Gal $\beta 1-3$ GalNAc $\alpha-R$. Glycobiology 1995; 5: 689-697.

40. O'Brien M, Mitsuoka T. Quantitative fluorometric assay for rapid enzymatic characterization of Bifidobacterium longum and related bifidobacteria. Microbiol Immunol 1991; 35: 1041-1047.

41. Roberton AM, McKenzie CG, Sharfe N, Stubbs LB. A glycosulphatase that removes sulphate from mucus glycoprotein. Biochem $J$ 1993; 239: 683-689.

42. Van Klinken BJ-W, Tytgat KMAJ, Büller HA, Einerhand AWC, Dekker J. Biosynthesis of intestinal mucins: MUC1, MUC2, MUC3 and more. Biochem Soc Trans 1995; 23: 814-818.

43. Porchet N, Pigny $\mathrm{P}$, Buisine MP et al. Human mucin genes: genomic organization and expression of MUC4, MUC5AC and MUC5B. Biochem Soc Trans 1995; 23: 800-805.

44. Gerken TA, Owens CL, Pasumarthy M. Determination of the site-specific $O$-glycosylation pattern of the porcine submaxillary mucin tandem repeat glycopeptide. J Biol Chem 1997; 272: 9709-9719.

45. Hansen W, Yourassowsky E. [Detection of glycosidases in Pseudomonas of the fluorescent group: relation between serotype and glycosidase activities in $P$. aeruginosa.] Ann Microbiol 1983; 134B: 411-419.

46. Forstner JF, Forstner GG. Gastrointestinal mucus. In: Johnson 
LR, Alpers DH, Jacobson ED, Christensen J, Walsh JH (eds) Physiology of the gastrointestinal tract, 3rd edn, vol 2. New York, Raven Press. 1994: 1255-1283.

47. Sajjan U, Reisman J, Doig P, Irvin RT, Forstner G, Forstner J. Binding of nonmucoid Pseudomonas aeruginosa to normal human intestinal mucin and respiratory mucin from patients with cystic fibrosis. J.Clin Invest 1992; 89: 657-665.

48. Jansen HJ, Hart CA, Saunders JR, Rhodes JM, Smalley JW. Oral streptococcal mucin-sulphatase activity. J Dent Res 1997; 76: 1059.

49. Murty VLN, Piotrowski J, Morita M, Slomiany A, Slomiany BL. Inhibition of Helicobacter pylori glycosulfatase activity toward gastric sulfomucin by nitecapone. Biochem Int 1992; 26: $1091-1099$.

50. Corfield AP, Wagner SA, Clamp JR, Kriaris MS, Hoskins LC Mucin degradation in the human colon: production of sialidase, sialate-O-acetylesterase, $\mathrm{N}$-acetylneuraminate lyase, arylester- ase, and glycosulfatase activities by strains of faecal bacteria. Infect Immun 1992; 60: 3971-3978.

51. Leprat R, Michel-Briand Y. Extracellular neuraminidase production by a strain of Pseudomonas aeruginosa isolated from cystic fibrosis. Ann Microbiol 1980; 131B: 209-222.

52. Scharfman A, Ramphal R, Neut C, Carnoy C, Lamblin G, Roussel P. Arylneuraminidase activity of Pseudomonas aeruginosa does not degrade natural substrates such as human respiratory mucins. Infect Immun 1991; 59: 4283-4285.

53. Carnoy C, Ramphal R, Scharfman A et al. Altered carbohydrate composition of salivary mucins from patients with cystic fibrosis and the adhesion of Pseudomonas aeruginosa. Am J Respir Cell Mol Biol 1993; 9: 323-334.

54. Vavasseur F, Dole K, Yang J et al. $O$-glycan biosynthesis in human colorectal adenoma cells during progression to cancer. Eur J Biochem 1994; 222: 415-424. 